\title{
Thoughts on Carrying out Scientific Research Work in Private Colleges and Universities
}

\author{
Fengxia Zhu \\ Peihua University \\ Xi'an, P. R. China
}

\begin{abstract}
With the popularization of higher education in China, private colleges and universities have played an increasingly important role in the cultivation of talents, and have become an important part of national education. It has become the consensus of the industry to promote the development of colleges and universities through scientific research. Based on the needs of economic transformation and personnel training, this paper analyzes the necessity of carrying out scientific research in private colleges and universities from the aspects of promoting the reform of teaching contents, supporting the development of enterprises, improving the quality of running schools and cultivating teachers, and finds out the problems existing in the development of scientific research in private colleges and universities at present. This paper puts forward some concrete suggestions and measures around the construction of scientific research system, the determination of scientific research direction, the construction of scientific research team and the construction of academic atmosphere, which provides a reference for the applied undergraduate colleges and universities to carry out scientific research work.
\end{abstract}

Keywords-Private colleges and universities; Applied type; Scientific Research work; Thoughts

\section{INTRODUCTION}

With the rapid development of science and technology such as artificial intelligence and big data, China's economic development has entered a new norm which has created new requirements for the supply and demand for talents. In order to meet the needs of social development and meet the needs of economic structure adjustment, industrial upgrading, social culture construction and other aspects, the State has continuously promoted the innovation development strategy drive, solved the structural contradiction and homogenization of higher education, actively promoted the applied reform of local undergraduate colleges and cultivated the applied talents with the first line of production service[1]. Private universities have been rapidly developed with the help of national and social support, accounting for $16.15 \%$ of all colleges and universities, which have become an indispensable part of higher education in China[2]. However, with the decrease of student sources and the rapid development of public local undergraduate colleges and universities, the survival competition of private colleges and universities is becoming more and fiercer.

Therefore, in the process of application-oriented reform and transformation, private colleges and universities should fully understand the importance and necessity of scientific research work closely follow the orientation of applied transformation and school development, systematically analyze the factors that affect scientific research work, and follow scientific research. This paper probes into the methods of carrying out scientific research work, promotes education and teaching with scientific research, and improves the training quality of applied talents.

\section{THE NECESSITY OF CARRYING OUT SCIENTIFIC} RESEARCH IN PRIVATE APPLIED COLLEGES AND UNIVERSITIES

\section{A. Scientific research achievements can deepen the reform of} education and teaching contents

The applied undergraduate course is the fusion of the new undergraduate education and the new higher vocational education, which is quite different from the research undergraduate education in the orientation of personnel training. The content of education and teaching should not only grasp the basic education, lay a good professional foundation, but also meet the requirements of the post and competent for the post responsibility. In the setting of teaching content of professional courses, we should highlight the characteristics of forwarding position, professionalism, comprehensiveness and dynamics. Forward position refers to the fact that the teaching content must be closely related to the development of disciplines and specialties, the dissemination and teaching of theoretical frontier issues. These characteristics raise higher requirements for teachers, who must strengthen scientific research, especially applied scientific research, and apply the research results to practical teaching, which can promote teaching reform and improve teaching quality.

\section{B. Scientific research can provide intellectual support for enterprise industry development}

Strengthening the deep integration with enterprises is a necessary way for the development and construction of applied undergraduate colleges and universities. Colleges and universities should give full play to the advantages of scientific research, provide technical and scientific research support for the development of enterprises, help enterprises to solve practical theoretical problems, and enhance the function of serving society. In view of the problems found in the practice of students' practice and the problems existing in the development of enterprises themselves, colleges and universities should be targeted to solve these problems, provide theoretical support and train of thought enlightenment for enterprises. This requires that the scientific research of applied undergraduate colleges and universities must pay close 
attention to the development process of enterprise construction, the realistic state, closely follow the reality of enterprise industry, strengthen the consciousness of problem, highlight the applied research, and play the role of scientific research in answering and solving the practical problems of the development of enterprise industry.

\section{Scientific Research Achievement is an important embodiment of the quality of running a School in Colleges and Universities}

In the present university evaluation system, the academic achievements of scientific research account for a large proportion, and the academic achievements of scientific research are the important embodiment of the construction level of disciplines and specialties in colleges and universities. Private applied undergraduate colleges and universities should pay close attention to the applied development, take training and solving practical problems, competent post responsibility applied talents training as the foundation, strengthen the problem consciousness, especially the practical problems and difficulties in the development and construction of enterprises, hot issues, is the key to professional skills teaching, but also an important way to produce high-quality scientific research achievements. Teachers must dig deep into the enterprise industry to understand that the enterprise needs to be solved urgently. In order to solve these problems, this paper will study and solve these problems as the focus of teaching work, as an important subject of scientific research. It is only possible to obtain good scientific research results if the teacher chooses the subject in cooperation with the enterprise, and solves the problem of the development of the enterprise.

\section{Scientific research can forge and develop the teaching staff}

The construction of teaching staff in private colleges and universities has always been a difficult problem. The human resources department is handling the formalities of entry and departure all the year-round and the team is very unstable. The source of teachers is mainly concentrated in Ph.D. and retired teachers in public colleges and universities. Scientific research work is an important starting point in the cultivation of teachers, which can condense teachers' ideas and be conducive to team building. The scientific research work of private colleges and universities is an important part of performance appraisal, which can bring certain economic benefits to teachers, at the same time; it is also professional title evaluation and double title evaluation. An important basis for the identification of teachers. Scientific research can arouse the enthusiasm of teachers in education and teaching and can apply the research results to classroom teaching. In scientific research, teachers can organize students to participate in scientific research projects, which is helpful to cultivate students' scientific research innovation ability, and can also build reserve force for school teachers.

\section{AN ANALYSIS OF THE FACTORS RESTRICTING THE DEVELOPMENT OF SCIENTIFIC RESEARCH IN PRIVATE COLLEGES AND UNIVERSITIES}

There are many factors restricting the development of scientific research in private colleges and universities, both internal and external. The internal reasons are mainly reflected in the self-development orientation of private colleges and universities, scientific research team, research direction, management system and other aspects, there are shortcomings in the scientific research management system and system construction, especially the lack of cultivating unique scientific research direction and scientific research team[3].

\section{A. The National Policy system needs to be further strengthened in supporting the Development and Construction of Private Colleges and Universities}

With the improvement of the policy system, the state has introduced relevant policies and regulations, and the private education in China has obtained the recognition and protection of the law, and established the status of the important part of its socialist education. In this status, it is difficult to enjoy the rights and benefits and the preferential support policies corresponding to their obligations and responsibilities in the case of annual review, taxation, land use, finance and the construction of the teaching staff. This policy limit has led to the fact that the bias of the society to the private colleges and universities has not been completely changed, and the superior The research work of the private university is not paid much attention, and the research work is marginalized. In the project establishment, priority should be given to the lack of access to the public universities and the information acquisition channels and it is difficult to obtain the support of scientific research funds.

\section{B. The top-level design of scientific research work is not enough, and there is a lack of systematic planning}

Because of the unique management mechanism of private colleges and universities, the orientation of school development is closely related to the personal preferences and related interests of the organizers. It is thought that there is a conflict between scientific research and teaching, artificially separating scientific research from teaching, and scientific research is not given due attention [4]. In the scientific research work, there is a lack of long-term top-level design, the teachers do not follow the laws of scientific research, and they are eager to achieve success, especially after the development of applied transformation, there is not enough research on the new situation and new problems, and busy with the transaction work. The long-term development of the subject research is basically blank, the scientific research work is still in the utilitarian stage, not included in the overall construction of colleges and universities, human, material resources, especially financial support is not very in place, so that the scientific research work lacks scientific systematic planning and subject guidance, team research has not yet been formed, resulting in scientific research academic achievements hovering at a low level, it is difficult to achieve high-level, high-quality, practical promotion and application value of the results.

\section{The development direction of scientific research is unstable and the characteristics are not prominent}

Due to the fact that private colleges and universities keep up with the demand of the job market, the adjustment of specialties is rapid, and the accumulation of subjects is not 
enough. In addition, the scientific research work of teachers in private colleges and universities is carried out on the premise of completing first-line teaching work. Due to the limitations of their energy, especially the discipline specialty, knowledge structure and scientific research ability, the research direction of their scientific research work has certain limitations. In addition, teachers study more alone, less teamwork, communicate with each other, the consciousness of joint research is not strong, do not take the initiative to engage in the horizontal alliance, and even build a car behind closed doors. Due to the dispersion of research power, there is no joint force, and the mobility of teachers is large, so it is difficult to form stable scientific research.

\section{The research academic atmosphere is poor; the research academic activity lacks the vigor}

The composition of teachers in private colleges and universities is relatively complex and the consciousness of scientific research is not strong and the old teachers have the idea of giving full play to waste heat and the enthusiasm to engage in scientific research work due to age and body, the academic accumulation of young teachers is not enough, they are busy with daily teaching and routine work, the scientific research work is painstaking, there is no strong willingness to participate in scientific research work, and no good scientific research academic atmosphere has been formed. In addition, there is no scientific performance policy guidance, in the management of scientific research, the characteristics of academic research are ignored, the role of the expert group is not enough, and the lack of organizing experts to participate in the management of academic research leads to the lack of a sense of responsibility and ownership of some of the backbone of scientific research.

\section{Measures to StREngthen SCIENTIFIC RESEARCH IN PRIVATE COLLEGES AND UNIVERSITIES}

It has become the inevitable requirement of applied construction for private applied colleges and universities to carry out high-quality scientific research. Scientific research work should be regarded as an important starting point in promoting educational and teaching reform, innovating entrepreneurial practice and school-enterprise cooperation, so as to improve the level of running and running schools in an all-round way[5].

\section{A. Scientific construction of scientific research organization management system}

Based on the long-term development, private colleges and universities should establish scientific research work planning, set up special institutions responsible for scientific research management, work hard in scientific research organization and team building, and perfect the system mechanism. Leaders at all levels of colleges and universities should attach great importance to, vigorously support and actively participate in scientific research, and leaders of secondary colleges should take the lead in carrying out major research. To form a multilevel, multi-form, multi-domain and multi-faceted scientific research organization system in which the organization is sound, the leadership division of labor is grasped, the responsibility is clearly carried out, the scientific research is carried out by some people, and the scientific research activities are carried out in many levels, forms, fields and directions, so as to lay a solid organizational foundation for the development of scientific research.

\section{B. Forming a relatively stable scientific research direction}

Scientific research needs continuous accumulation, and the scientific research direction of private colleges and universities should remain relatively stable in order to ensure the sustainable development of scientific research and achieve the desired results. The establishment of a relatively stable scientific research team is the premise of maintaining a stable research direction. More efforts should be made to select the direction and determine the subject, especially to keep up with the social needs and industrial development. Around the frontier of the subject and the construction of the discipline specialty in colleges and universities, the characteristics and advantages of the subject specialty in university should be analyzed, and the feasible scientific research development strategy and development plan should be worked out. In the topic selection of scientific research, we should pay attention to the frontier and development direction of subject specialty, drive the construction of subject specialty with the subject; promote the integration of industry and education and the cooperation between school and enterprise.

\section{Strengthening the Construction of Scientific Research academic team}

The construction of scientific research backbone team should focus on the construction of the subject specialty, make the construction plan scientifically, and carry out the introduction and training of talents step by step. When emphasizing team building and establishing the backbone object of training, we should comprehensively evaluate and examine the theoretical background of the training object, scientific research achievements, master the frontier degree of subject development, select the training object with a solid foundation and love the scientific research work, and establish the training object. The state adjustment mechanism promptly absorbs outstanding young teachers to join the scientific research team and eliminates those who are not conducive to team building. Private colleges and universities should actively organize targeted scientific research backbone training, invite enterprises and scientific research experts and subject leaders to give lectures on scientific research knowledge, at the same time, establish an in-school exchange and training mechanism, give full play to the advantages of a wide range of sources of teachers in private colleges and universities, and absorb the experience of various scientific research work. Actively organize the backbone of scientific research to other colleges and enterprises to carry out research, learn from the advanced experience of scientific research, and carry out scientific research cooperation between schools and enterprises. Actively build a scientific research exchange and cooperation platform to attract more outstanding talents to join the scientific research of private colleges and universities. 


\section{Creating strong scientific research and academic atmosphere}

It is particularly important for teachers to promote scientific research in private colleges and universities by creating an academic atmosphere in which teachers love scientific research and drill scientific research[6]. Private colleges and universities fully carry out the role of scientific research performance command, formulate incentive policies, encourage scientific research, and gradually form a good academic atmosphere. Expand the concept of scientific research to all fields of education and teaching, carry out classified management on natural science research, social science research, basic science research and teaching management, and fully mobilize the majority of teachers to carry out scientific research. The enthusiasm for work should be given full play to the role of material rewards and spiritual incentives in promoting scientific research, build typical, set a benchmark, gradually form an atmosphere for everyone to participate in scientific research and research, and improve the overall research level.

\section{CONCLUSION}

As an important part of applied undergraduate colleges and universities, private colleges and universities play an important role in the national vocational education system and play a more and more important role in cultivating applied talents suitable for regional economic development and future social needs. In the scientific research work of private colleges and universities, it is necessary to strengthen the top-level design, scientific planning, based on the long-term development of scientific research, create a scientific research academic atmosphere, closely follow the orientation of running a school, carry out scientific research academic research, unify scientific research and education and teaching, and build a team that integrates teaching and scientific research. After a certain period of precipitation, private colleges and universities will certainly build a high level of applied universities.

\section{REFERENCES}

[1] http://www.moe.gov.cn/srcsite/A03/moe_1892/moe_630/201511/t20151 113_218942.html

[2] http://www.moe.gov.cn/jyb_xxgk/s5743/s5744/201906/t20190617_3862 00.html

[3] Wang Xinhong.The factors Restricting the scientific Research Level of private Colleges and Universities in Henan Province [J].China Management Informationization, 2012(3)93-95.

[4] Guo Zhanyuan. The Promotion and Sustainable Development of Scientific Research ability in Private Colleges and Universities. Modern Educational Science, 2009(4):53-55.

[5] Qin Fengxiang. Research on Advancing Scientific Research Work of Private Higher Colleges from the Perspective of Internal Management[J].Journal of Hubei Correspondence University, 2018, 31(13):36-37.

[6] Liu Rui, Guo Yungui, Zhang Lihua. The influence of the academic atmosphere and Scientific Research input on the Scientific Research performance of Teachers in Colleges and Universities[J].Modern Management Science, 2016, (10):97-99. 